\title{
Transcription factor mutations as a cause of familial myeloid neoplasms
}

\author{
Jane E. Churpek ${ }^{1}$ and Emery H. Bresnick ${ }^{2}$ \\ 'Section of Hematology/Oncology and Center for Clinical Cancer Genetics, The University of Chicago, Chicago, Illinois, USA. ${ }^{2}$ UW-Madison Blood Research Program, Department of Cell and Regenerative \\ Biology, Wisconsin Institutes for Medical Research, UW Carbone Cancer Center, University of Wisconsin School of Medicine and Public Health, Madison, Wisconsin, USA.
}

\begin{abstract}
The initiation and evolution of myelodysplastic syndrome (MDS) and acute myeloid leukemia (AML) are driven by genomic events that disrupt multiple genes controlling hematopoiesis. Human genetic studies have discovered germline mutations in single genes that instigate familial MDS/AML. The best understood of these genes encode transcription factors, such as CATA-2, RUNX1, ETV6, and C/EBP $\alpha$, which establish and maintain genetic networks governing the genesis and function of blood stem and progenitor cells. Many questions remain unanswered regarding how genes and circuits within these networks function in physiology and disease and whether network integrity is exquisitely sensitive to or efficiently buffered from perturbations. In familial MDS/AML, mutations change the coding sequence of a gene to generate a mutant protein with altered activity or introduce frameshifts or stop codons or disrupt regulatory elements to alter protein expression. Each mutation has the potential to exert quantitatively and qualitatively distinct influences on networks. Consistent with this mechanistic diversity, disease onset is unpredictable and phenotypic variability can be considerable. Efforts to elucidate mechanisms and forge prognostic and therapeutic strategies must therefore contend with a spectrum of patient-specific leukemogenic scenarios. Here we illustrate mechanistic advances in our understanding of familial MDS/AML syndromes caused by germline mutations of hematopoietic transcription factors.
\end{abstract}

\section{Introduction}

High-throughput sequencing has revolutionized molecular medicine. In hematology, genomic technologies have unveiled the complex genomic landscape of blood pathologies including myelodysplastic syndrome (MDS) and acute myeloid leukemia (AML) (1-3). The formidable challenge now is to decipher vast genetic blueprints harboring abundant "variants of undetermined significance" to discover clinically important aberrations. Major efforts focus on elucidating how single mutations or combinations thereof cause MDS and AML and impact treatment responsiveness or resistance.

The study of familial MDS/AML has unique power to identify leukemogenic drivers and elucidate multistep mechanisms in which a risk allele enables acquisition of additional mutations or confers hypersensitivity to secondary insults, either genetic or environmental, thus causing progressive bone marrow (BM) failure and/or MDS/AML. Since the identification of RUNX1 as the first nonsyndromic monogenic familial MDS/AML gene (4), more than 65 genes with diverse biologic functions have been implicated in contributing to MDS/AML risk (Table 1, Table 2, and refs. 5-7). Efforts to catalog the diverse clinical phenotypes, disease penetrance and latency, germline mutation spectra, and cooperating acquired mutations have provided insight into the organ systems and cell lineages that rely on each gene. These data also inform how each germline mutation uniquely disrupts protein function(s), whether it generates haploinsufficiency,

Conflict of interest: The authors have declared that no conflict of interest exists. Reference information: / Clin Invest. 2019;129(2):476-488.

https://doi.org/10.1172/JCI120854. dominant-negative or ectopic protein functions, or amalgamated gain-of-function and loss-of-function defects to disrupt cellular phenotypes and instigate MDS/AML.

Among MDS/AML risk loci, GATA2, RUNX1, ETV6, and $C E B P A$ encode transcription factors with vital functions to control hematopoietic stem and progenitor cell (HSPC) development and differentiation. Comparing and contrasting phenotypes caused by germline and somatic mutations in these genes in mouse and human systems has yielded fundamental insights into the complexity and interconnectedness of networks that govern hematopoiesis. This Review describes how germline mutations dysregulating hematopoietic transcription factors in familial MDS/AML inform pathogenesis.

\section{GATA-2 deficiency syndrome}

Mechanistic foundations. Germline GATA2 coding and regulatory element mutations cause immunodeficiency, MDS/AML, lymphatic vascular dysfunction, and other complex phenotypes (Table 3) (8-13). To understand how distinct mutations in one gene instigate diverse pathologies, it is instructive to rigorously establish a foundation for GATA2 function at the molecular, cellular, and physiological levels.

The discovery of the founding member of the GATA transcription factor family, GATA-1, initiated a richly productive phase of research that unveiled numerous mechanistic insights. As reviewed elsewhere $(14,15)$, efforts to elucidate mechanisms governing developmental changes in globin gene expression identified a transcription factor termed GATA-1 $(16,17)$ that bound with specificity to WGATAR-containing DNA (18-20). Targeted deletion of murine Gata1 abolished definitive erythropoiesis, yielding 
Table 1. Mutations in DNA repair genes implicated in cellular mechanisms of familial MDS/acute leukemia

Base excision repair

MBD4
Homologous

recombination

ATM, FANCA, FANCB, FANCC, BRCA2 (FANCD1), FANCD2, FANCE,

FANCF, FANCG, FANCI, BRIPI, (FANCI), FANCL, FANCM,

PALB2 (FANCN), RAD51C (FANCO), SLX4 (FANCP), ERCC4 (FANCO),

RAD51 (FANCR), BRCA1 (FANCS), UBE2T (FANCT), XRCC2 (FANCU),

REV7 (FANCV) anemia and embryonic lethality (21). GATA-1 also controls megakaryocyte (22), eosinophil (23), and basophil (24) differentiation.

In contrast to lineage-restricted GATA-1 functions, targeted deletion of Gata2 abrogates multilineage hematopoiesis (25). This discovery established GATA-2 as the first protein that endows hematopoietic stem cells (HSCs) with the capacity to generate all blood cells. Studies of mice with conditional deletions of Gata2 and Gata2 enhancer mutations (12, 26-31) extended its vital developmental activity to adult hematopoiesis and delineated GATA-2dependent cellular/molecular steps and genetic networks (Figure 1) controlling hematopoiesis. GATA-1 and GATA-2 function through multimeric complexes assembled on WGATAR motifs or E-boxspacer-WGATAR composite elements $(20,32)$. Despite having the capacity to function through the same motif at the same locus (in different developmental contexts), the influence of GATA-1 versus GATA-2 on transcription can differ. Furthermore, reducing the levels of GATA factor complex components can differentially impact GATA factor-dependent target gene ensembles (33).

GATA-2 is an unstable protein $\left(t_{1 / 2}<1\right.$ hour) degraded by the ubiquitin-proteasome system $(34,35)$. During embryogenesis, BMP4 induces GATA-2 expression $(36,37)$. The blood- and vascular-regenerative transcription factor ETV2 (38-40), one of the approximately 30-member ETS transcription factor family that also includes ETV6, occupies the Gata2 locus (41). GATA2 also occupies conserved noncoding DNA regions in the Gata2 locus that assemble GATA-2 and GATA-1 complexes in a contextdependent manner (42-44). Gata2 transcription positively correlates with GATA-2 occupancy at these sites, implying autoregulation $(14,15,42)$. In contrast, GATA-1/FOG-1-dependent displacement of GATA-2 from these chromatin sites, deemed a GATA switch, represses Gata2 expression, which enables erythroid precursors to progressively mature into erythrocytes $(14,43)$.

Mutant mice lacking individual "GATA switch sites" demonstrate essential activities of enhancers +9.5 and $-77 \mathrm{~kb}$ relative to the Gata2 transcription start site (Figure 2) for hematopoiesis and embryogenesis $(12,29)$. The +9.5 intronic enhancer triggers HSC emergence in hemogenic endothelium of the aorta-gonadmesonephros (AGM) region of the embryo, and its deletion depletes HSCs $(12,28)$. The -77 distal enhancer regulates myeloid progenitor differentiation but not HSCs or function in the mouse embryo (29). Individual emergence of deletions of the other GATA switch sites $(-1.8,-2.8$, and -3.9) (44-46) have little or no impact on hematopoiesis (47-49).

Why do deletions of different enhancers at the same locus yield embryonic lethality, yet differentially affect hematopoiesis? Compound-heterozygous mice lacking one copy each of the +9.5 and -77 enhancers on different chromosomes are embryonic lethal, which resembles homozygous deletions of either enhancer alone (50). These compound heterozygous mice exhibit normal HSC emergence but defective myeloid progenitors. While one +9.5 copy suffices to induce HSC emergence, the +9.5 and -77 enhancers must reside on the same chromosome for normal progenitor biology. This mechanism, in which both enhancers function in concert in progenitors, but not in HSCs, exemplifies the context-dependent nature of GATA-2 regulation.

Downstream of GATA-2 expression, GATA-2-regulated genetic networks are highly context-dependent $(12,28,29,50$, $51)$, involving variable composition and activity of coregulators and transcription factors within distinct cell types and even subnuclear domains within a single cell type. For example, in eryth-

Table 2. Mutations in diverse genes implicated in cellular mechanisms of familial MDS/acute leukemia

\begin{tabular}{|c|c|c|c|c|c|c|c|c|c|}
\hline $\begin{array}{l}\text { DNA damage- } \\
\text { sensing }\end{array}$ & $\begin{array}{c}\text { Cell } \\
\text { proliferation }\end{array}$ & $\begin{array}{l}\text { Cytokine } \\
\text { signaling }\end{array}$ & $\begin{array}{c}\text { Hematopoietic } \\
\text { transcription } \\
\text { factors }\end{array}$ & $\begin{array}{l}\text { Neutrophil } \\
\text { biology }\end{array}$ & $\begin{array}{c}\text { Protein } \\
\text { ubiquitination }\end{array}$ & $\begin{array}{c}\text { RAS } \\
\text { pathway }\end{array}$ & $\begin{array}{l}\text { Ribosome } \\
\text { biology }\end{array}$ & $\begin{array}{l}\text { Telomere } \\
\text { biology }\end{array}$ & $\begin{array}{l}\text { Unresolved } \\
\text { mechanism }\end{array}$ \\
\hline TP53 & SAMD9, SAMD9L & SH2B3 & $\begin{array}{l}\text { CEBPA, ETV6, } \\
\text { GATA1, GATA2, } \\
\text { IKZF1, MECOM1, } \\
\text { PAX5, RUNX1 }\end{array}$ & $\begin{array}{l}\text { CSF3R, ELANE, } \\
\text { WAS }\end{array}$ & RBBP6 & $\begin{array}{c}\text { CBL, NF1, } \\
\text { PTPN11 }\end{array}$ & $\begin{array}{c}\text { RPL11, RPL5, } \\
\text { RPS19, } \\
\text { RPS26, } \\
\text { SBDS, } \\
\text { SRP54 }\end{array}$ & $\begin{array}{c}\text { ACD, CTC1, DKC1, } \\
\text { NAF1, NHP2, } \\
\text { NOP10, PARN, } \\
\text { POT1, RTEL1, } \\
\text { TERC, TERT, } \\
\text { TINF2, USB1, } \\
\text { WRAP53 }\end{array}$ & $\begin{array}{c}\text { ANKRD26, } \\
\text { ATG2B (GSKIP), } \\
\text { DDX41, } \\
\text { SRP72 }\end{array}$ \\
\hline
\end{tabular}

This table includes genes in the listed pathways that have been observed in at least one patient who developed MDS or acute leukemia. Additional genes in these pathways that have been observed only in bone marrow failure presentations are not included. 
A

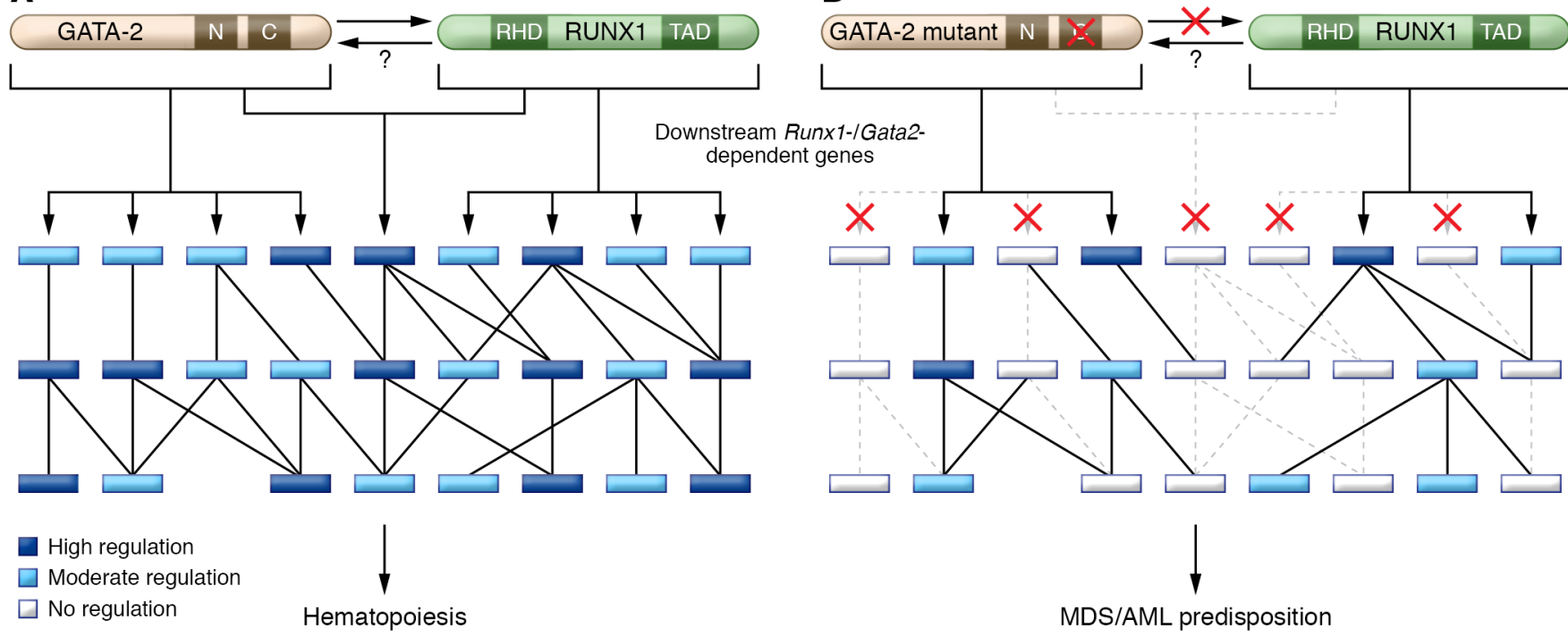

Figure 1. Ensuring normal hematopoiesis by establishing and maintaining genetic network integrity. The diagram on the left depicts the GATA-2dependent increase in RUNX1 expression $(28,99)$, and both independent and collective functions of these transcription factors to establish and maintain genetic networks. The question mark denotes uncertainty as to whether RUNX1 might control GATA-2 expression. The diagram on the right depicts how an inhibitory GATA-2 C-finger mutation corrupts network integrity. The model assumes that network integrity ensures normal hematopoiesis, and numerous opportunities exist to corrupt integrity, thereby creating a predisposition or vulnerability to a battery of genetic or environmental insults that trigger pathogenesis. For simplicity, the diagram illustrates GATA-2 and RUNX1 actions, yet numerous components are involved, including other genes and their respective proteins subject to germline mutations that create a predisposition for MDS/AML, e.g., C/EBP $\alpha$. In addition, there may be instances in which GATA-2-dependent pathogenesis is independent of RUNX1 and vice versa. The rectangles at the bottom represent individual genes, with the colors representing variable levels of gene activity. The white rectangles within the corrupted network reflect little or no transcriptional regulation. Red X, blocked path; hatched line, disrupted regulatory connection. N, N-finger; C, C-finger; RHD, Runt homology domain; TAD, transactivation domain.

roid precursors, GATA-2 induces Gata1 and Kit transcription (50). GATA-1 represses Kit transcription $(52,53)$ to promote prodifferentiation erythropoietin signaling (54) and represses Gata2 transcription $(43,55-57)$. In HSPCs, GATA-2 induces $20 \mathrm{G}$ protein-coupled receptors, including GPR65 (58). Downregulating GPR65 increases HSC emergence as a result of a negative-feedback loop that establishes repressive chromatin, restricts Scl/TAL1 occupancy at the +9.5 enhancer, and decreases Gata2 transcription (58). In the AGM, GATA-2 induces RUNX1 and other transcriptional regulators of hematopoiesis, including Scl/TAL1 and the zinc finger proteins GFI1 and GFI1b (28). Because these transcription factors establish/maintain genetic networks (59-61), and because GATA- 2 is expressed in cells containing these factors, the networks are interdigitated, and a subset of the components are coregulated (Figure 1). How these networks parse into circuits involving autoregulatory, feed-forward, and feedback loops and how circuits interdigitate to establish, maintain, buffer, and remodel network integrity to mediate GATA-2 function are of considerable interest. Deciphering the context-dependent mechanisms governing GATA2 regulation and function will be critical to understand and treat the diverse GATA-2-dependent pathologies in humans.

GATA-2 dysfunction in human pathologies. As expected from the discoveries described above in mouse models, acquired mutations in human GATA2 are associated with multiple pathologies (Table 3). Although GATA2 mutations are relatively rare, occurring in less than $5 \%$ of MDS/AML cases overall (Table 4 ), specific subsets are enriched for different GATA2 mutations. An acquired recurrent mutation (p.L359V) in the DNA-binding carboxy- terminal zinc finger (C-finger) domain was reported in 9\% (8 of 85) of accelerated- or blast-phase chronic myeloid leukemia (CML) cases $(62,63)$. In reporter assays, p.L359V-mutated GATA-2 exhibited greater activation and repression activities, in comparison with wild-type GATA-2, consistent with a gain of function. In mice, p.L359V cooperated with BCR/ABL to induce myelomonocytic leukemia. In contrast, GATA-2 N-terminal zinc finger ( $\mathrm{N}$-finger) mutations are acquired in $20 \%-39 \%$ of biallelic $\mathrm{C} / \mathrm{EBP} \alpha$-mutated AML (64). However, the function of the $\mathrm{N}$-finger, which differs from the $\mathrm{C}$-finger in not being required for binding to WGATAR sequences (65), and how acquired N-finger mutations alter GATA-2 activity are unclear.

Heterozygous germline GATA2 mutations cause diverse clinical presentations, including familial MDS/AML alone (9), MonoMAC and DCML syndromes (immunodeficiency syndromes featuring monocytopenia, B cell, NK cell, and dendritic cell deficiencies along with pulmonary alveolar proteinosis and/or unusual or severe infections including disseminated nontuberculosis mycobacterium, extensive HPV-related warts, and opportunistic fungal or viral infections) $(10,11,66)$, Emberger syndrome (primary lymphedema with predisposition to MDS/AML) (8), chronic neutropenia (67), pediatric or young adult-onset MDS often with monosomy $7(68,69)$, and aplastic anemia $(70)$. These presentations are now considered to be the spectrum of a single disease entity, termed GATA-2 deficiency syndrome.

Another enigmatic feature of GATA-2 deficiency syndrome is the highly variable time of symptom onset (71). While symptoms can present in young children, adults can be asymptomatic, 


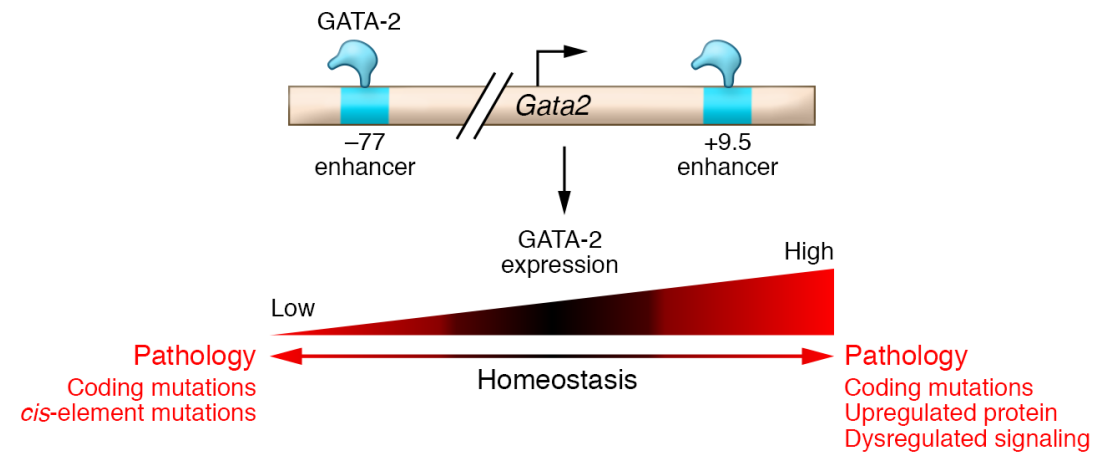

Figure 2. Pathogenic consequences of GATA-2 deficiency and excess. Physiological CATA-2 levels in HSPCs are conferred by the Gata2 +9.5 and -77 enhancers in the mouse, and these enhancers are conserved in humans (14). While the enhancers are GATA-2-occupied, the ensemble of proteins and mechanisms governing enhancer activities are not yet known. Deviations from a physiological window of GATA-2 expression, either deficiency or excess, are pathogenetic (14). Coding region mutations decrease or increase GATA-2 levels and/or activity, and these alterations can be locus-specific (84). GATA-2 enhancer mutations decrease GATA-2 levels (12, 13). Since GATA-2 hyperphosphorylation increases GATA-2 activity in a locus-specific manner $(183,184)$, presumably, dysregulated cell signaling mechanisms can also yield excessive GATA-2 activity.

suggesting that a germline heterozygous GATA2 mutation alone is insufficient for disease. Either mechanisms suppress GATA2 mutation-instigated pathogenesis, or other genetic or environmental insults constitute the breaking point for overt disease development. In line with this hypothesis, even before peripheral blood (PB) cytopenias develop, clonal hematopoiesis is evident in the $\mathrm{PB}$ via skewed $\mathrm{X}$ chromosome inactivation (72). This may progress to an aplastic anemia-like presentation $(69,70)$, reminiscent of HSPC loss in GATA-2-deficient murine models. However, acquisition of a second GATA2 mutation at the time of MDS or marrow failure in human disease has not been reported.

Also consistent with a mechanism in which additional aberrations are disease triggers, the risk of overt hematologic malignancy development increases with age from about $10 \%$ by age 10 to $50 \%-80 \%$ by age 40 (72-74). Most initial presentations involve MDS featuring hypocellularity, atypical megakaryocytes, fibrosis, and acquired cytogenetic abnormalities, of which monosomy 7 and trisomy 8 are the most frequent $(68,73,74)$. ASXL1 mutations are acquired at the time of malignancy in about $30 \%$ of cases and correlate with a chronic myelomonocytic leukemia (CMML) phenotype and monosomy 7 (75-79), suggesting cooperation between these genetic lesions and the germline GATA2 mutation in malignant progression. SETBP1 and STAG2 mutations are also recurrent in this setting $(77,80)$.

A unique case study of multiple members of a family with the recurrent germline p.T354M mutation provided clues regarding mechanisms underlying symptom onset. One family member exhibited monoallelic expression of the mutated allele during a symptomatic period early in life, but regained biallelic expression later when her PB counts and BM normalized (79). She also carried an acquired ASXL1 mutation that persisted for 6 years without progression to overt malignancy, suggesting that combined GATA2 and ASXL1 mutations alone are insufficient for MDS/AML. Her father and uncle, carriers of the familial mutation, had biallelic GATA2 expression and remained asymptomatic into adulthood. This study implicates epigenetic control of GATA2 expression and possibly symptom onset in humans with heterozygous mutations, consistent with epigenetic regulation of mouse Gata2 (43, 46, 58, 81, 82). Environmental factors, e.g., infection or other stresses that can sculpt epigenomes (83), might also trigger pathogenesis, but these remain poorly defined.

More than 100 unique GATA2 germline mutations have been reported. From the three largest series $(67,68,73,74)$, approximately $45 \%$ are missense or small in-frame insertions or C-finger deletions. C-finger residues p.T354, p.R361, p.R396, and p.R398 are recurrent germline missense mutation sites. Forty percent yield truncations prior to or within the C-finger, $5 \%$ are whole gene deletions, and $10 \%$ reside in the +9.5 enhancer $(68,73,74)$. De novo mutations are frequent, seen in $22 \%$ (6 of 27) of those presenting with chronic neutropenia or GATA-2 deficiency symptoms and $70 \%$ (7 of 10) of children/adolescents with MDS lacking a history of GATA2-related symptoms.

Despite growing reports of mutations, the heterogeneous disease presentations, small patient cohorts, rarity of individual mutations, and dearth of biologically instructive in vitro assays have made rigorous genotype/phenotype correlations difficult to establish. A recent analysis of p.T354M and p.R307W function in a genetic complementation assay in primary cells from Gata2 -77 enhancer mutant mice revealed defective activity at certain loci, with retention of activity or even hyperactivity at other loci (84). The locus-specific dysregulation of GATA-2 activity suggests that disease phenotypes involve an amalgamation of loss-offunction and gain-of-function phenotypes (Figure 2). In vivo correlations observed across two or more human patient series currently include differences in symptom penetrance, immunodeficiency, MDS/AML risk, and lymphedema prevalence. Nearly complete penetrance of GATA-2 deficiency-related symptoms was observed in carriers of truncating or deletion-type mutations, whereas a small subset of carriers of missense and +9.5 enhancer mutations remain asymptomatic into adulthood $(68,79,85)$. Interindividual comparisons of disease phenotypes, including in related individuals carrying p.T354M and p.R396Q, have suggested a lower cumulative incidence of immunodeficiency but a higher cumulative incidence of MDS/AML with p.T354M (85). It remains to be determined whether additional shared genetic or environmental risk factors explain these differences or whether the functional consequences of individual mutations can be distinct. Lymphedema is more frequent in carriers of null mutations (72, $74)$ and with some missense mutations $(8,73)$. Mutation-specific effects on GATA-2 activity impact its function through the PROX1 enhancer $(86,87)$. PROX1 encodes a lymphatic development regulator (88), and disruption of GATA-2-dependent PROX1 regulation constitutes a cell type-specific mechanism underlying one facet of GATA-2 deficiency syndrome. Establishing mutation- and context-specific associations involving other components of the pathologies will guide the development of organ-specific therapies. 
Table 3. Hematopoietic transcription factors implicated in familial MDS/acute leukemia syndromes: germline presentations

\begin{tabular}{|c|c|c|c|c|c|c|c|}
\hline \multirow[b]{2}{*}{ Gene } & \multicolumn{3}{|c|}{ Hematologic malignancy characteristics } & \multirow{2}{*}{$\begin{array}{l}\text { Other hematologic } \\
\text { manifestations }\end{array}$} & \multirow{2}{*}{$\begin{array}{l}\text { Other organ system } \\
\text { manifestations }\end{array}$} & \multirow{2}{*}{$\begin{array}{l}\text { Inheritance pattern and } \\
\text { penetrance }\end{array}$} & \multirow[b]{2}{*}{ References } \\
\hline & Type(s) & Karyotype & Acquired mutations & & & & \\
\hline CEBPA & $\begin{array}{l}\text { AML often with } \\
\text { abnormal } \\
\text { eosinophils }\end{array}$ & Normal karyotype & $\begin{array}{c}\text { Second CEBPA mutation } \\
\text { (100\%), CATA2 (56\%; } \\
\text { in ZF1), WT1 (33\%), } \\
\text { EZH2, SMC3, TET2, } \\
\text { NRAS, others }\end{array}$ & None & None & $\begin{array}{l}\mathrm{AD} \text { with near-complete } \\
\text { penetrance for } \mathrm{AML}\end{array}$ & $171-173$ \\
\hline GATA2 & $\begin{array}{l}\text { MDS, CMML, } \\
\text { AML, } \\
\text { T cell ALL }\end{array}$ & $\begin{array}{l}\text { Monosomy } 7 \text {, } \\
\text { trisomy 8, normal } \\
\text { karyotype, } \\
\text { complex or other } \\
\text { karyotypes }\end{array}$ & $\begin{array}{l}\text { ASXL1 }(29 \%), \text { SETBP1, } \\
\text { STAG2, others }\end{array}$ & $\begin{array}{c}\text { Monocytopenia } \\
\text { (49\%-78\%), } \\
\text { B lymphopenia } \\
(78 \%-100 \%), \text { NK cell } \\
\text { lymphopenia, CD4 }{ }^{+} \mathrm{T} \\
\text { lymphopenia, neutropenia, } \\
\text { anemia, thrombocytopenia, } \\
\text { aplastic anemia } \\
\text { (uncommon) }\end{array}$ & $\begin{array}{c}\text { Lymphedema (11\%-20\%), } \\
\text { infections (mycobacterial } \\
\text { [20\%-50\%], viral [10\%- } \\
20 \%] \text {, fungal [9\%-16\%], } \\
\text { bacterial), HPV-related } \\
\text { warts (60\%-70\%), } \\
\text { pulmonary alveolar } \\
\text { proteinosis or other lung } \\
\text { abnormalities, venous } \\
\text { and arterial thromboses, } \\
\text { miscarriage, autoimmunity }\end{array}$ & $\begin{array}{l}\mathrm{AD} \text { with variable penetrance } \\
\text { for all features, but high } \\
\text { penetrance for hematologic } \\
\text { malignancies }\end{array}$ & $\begin{array}{l}8-13 \\
66-80\end{array}$ \\
\hline ETV6 & $\begin{array}{l}\text { B cell ALL, } \\
\text { MDS, CMML, } \\
\text { AML, MM }\end{array}$ & $\begin{array}{l}\text { B-ALL: high } \\
\text { hyperdiploidy } \\
(64 \%)\end{array}$ & & $\begin{array}{l}\text { Thrombocytopenia (100\%), } \\
\text { platelet dysfunction, } \\
\text { macrocytosis } \\
\text { (uncommon) }\end{array}$ & $\begin{array}{l}\text { Mild learning deficits? } \\
\text { GI motility deficits or } \mathrm{Gl} \\
\text { cancers? }\end{array}$ & $\begin{array}{l}\text { AD with near-complete } \\
\text { penetrance for low platelets; } \\
\text { variable penetrance for } \\
\text { hematologic malignancies }\end{array}$ & $149-156$ \\
\hline IKZF1 & $\begin{array}{l}\text { Pre-B-ALL, } \\
\text { T cell ALL }\end{array}$ & $\begin{array}{l}\text { High hyperdiploidy } \\
\text { (38\%), } \\
\text { ETV6-RUNX1, MLL, } \\
\text { and other } \\
\text { rearrangements; } \\
\text { 9p loss }\end{array}$ & $\begin{array}{l}\text { PAX5 (19\%), } \\
\text { KRAS or NRAS } \\
\text { (26\%), TP53, } \\
\text { JAK2, FLT3, MTOR }\end{array}$ & $\begin{array}{c}\text { Common variable } \\
\text { immunodeficiency with } \\
\text { low immunoglobulin levels, } \\
\text { B and T cell } \\
\text { deficits; myeloid deficits } \\
\text { also seen with dominant- } \\
\text { negative alleles } \\
\text { (p.N159T/S in ZF2) }\end{array}$ & $\begin{array}{l}\text { Autoimmunity, } \\
\text { infections (bacterial, } \\
\text { fungal, viral) }\end{array}$ & $\mathrm{AD}$ with variable penetrance & 189-193 \\
\hline
\end{tabular}

\section{Disorders caused by RUNX1 and ETV6 mutations}

The autosomal dominant disorders familial platelet disorder with propensity to myeloid malignancy (FPDMM) and thrombocytopenia 5 (THC5), caused by heterozygous mutations in RUNX1 and ETV6, respectively, share the clinical triad of thrombocytopenia with normal platelet size, mild bleeding tendency, and hematopoietic malignancy predisposition. Given the similarities, it is instructive to consider mechanistic links between these genes and their phenotypes.

\section{Familial platelet disorder with propensity to myeloid malignancy (FPDMM)}

Mechanistic foundations. RUNX1, formerly known as acute myeloid leukemia protein 1 (AML1), resembles GATA-2 in functioning as a master regulator of definitive hematopoiesis. RUNX1 encodes the $\alpha$ subunit that dimerizes with a $\beta$ subunit to yield a functional core binding factor $(\mathrm{CBF})$ heterodimeric transcription factor that binds the DNA consensus YGYGGTY and activates or represses transcription $(89,90)$. The RUNX1 Runt domain characterizes a small transcription factor family (91) and mediates CBF- $\beta$ dimerization and DNA binding (92-94).

Targeted deletion of murine Runx 1 is embryonic lethal and is associated with defective fetal liver hematopoiesis, reduced HSPC genesis/function, and hemorrhaging (95-98). During the endothelial-to-hematopoietic transition in the AGM, GATA-2 increases Runx1 expression (ref. 28 and Figure 1). GATA and ETS motifs within a Runx1 $+23.5-\mathrm{kb}$ intronic enhancer are required for hematopoietic activity in transgenic mice (99), suggesting that GATA-2 directly activates Runx1. GATA-2 and RUNX1 can occupy neighboring chromatin sites, along with an ensemble of other factors $(100,101)$, implying their collective function in certain contexts. As RUNX1 controls HSC emergence from the AGM (102-104) and hemogenic endothelium function in vitro (105), it is attractive to consider a model in which GATA-2 activates RUNX1 expression in hemogenic endothelium and/or its cell progeny, and both factors function collectively (and perhaps independently) at a target gene ensemble to establish genetic networks that orchestrate HSPC 


\section{Table 4. Hematopoietic transcription factors implicated in familial MDS/acute leukemia syndromes:} germline versus acquired genetic variation

\begin{tabular}{|c|c|c|c|c|c|c|c|}
\hline Gene & $\begin{array}{l}\text { Hematopoietic phenotypes } \\
\text { in knockout mice }\end{array}$ & $\begin{array}{c}\text { Germline mutation types } \\
\text { and locations }\end{array}$ & $\begin{array}{l}\text { Germline mutation } \\
\text { frequency }\end{array}$ & $\begin{array}{l}\text { Acquired mutation } \\
\text { types and locations }\end{array}$ & $\begin{array}{l}\text { Acquired mutation } \\
\text { frequency }\end{array}$ & $\begin{array}{l}\text { Impact of acquired } \\
\text { mutations on } \\
\text { hematologic } \\
\text { malignancy prognosis }\end{array}$ & References \\
\hline CEBPA & $\begin{array}{l}\text { Myeloid maturation block } \\
\text { similar to M2 AML }\end{array}$ & $\begin{array}{l}\text { N-terminal frameshift prior } \\
\text { to second ATC (majority), } \\
\text { C-terminal leucine zipper } \\
\text { in-frame insertions or } \\
\text { deletions (rare) }\end{array}$ & AML: $1 \%$ & $\begin{array}{l}\text { N-terminal frameshift } \\
\text { prior to second ATG, } \\
\text { C-terminal leucine } \\
\text { zipper in-frame } \\
\text { insertions or deletions }\end{array}$ & AML: $4 \%$ & $\begin{array}{l}\text { AML: favorable } \\
\text { prognosis in biallelic } \\
\text { CEBPA-mutated cases }\end{array}$ & $\begin{array}{l}1,162,164 \\
170-176\end{array}$ \\
\hline GATA2 & $\begin{array}{l}\text { Embryonic lethal; abrogates } \\
\text { multilineage hematopoiesis }\end{array}$ & $\begin{array}{l}\text { Missenses or small in-frame } \\
\text { insertions or deletions } \\
\text { in C-terminal ZF (45\%) } \\
\text { (p.T354M, p.R361, p.R396, } \\
\text { and p.R398 are recurrent } \\
\text { sites); truncating prior to } \\
\text { C-terminal ZF (40\%); intron } \\
5 \text { ("+9.5") enhancer (10\%); } \\
\text { large deletions ( } 5 \%)\end{array}$ & $\begin{array}{l}\text { Childhood MDS: } 7 \% \text {; } \\
\text { chronic neutropenia: } \\
6 \text { of } 14 \text { probands with } \\
\text { other GATA2 features; } \\
\text { adult MDS/AML/ } \\
\text { CMML: unknown }\end{array}$ & $\begin{array}{c}\text { Accelerated-/blast- } \\
\text { phase CML: } 10 \% \text { and } \\
\text { located in C-terminal } \\
\text { ZF (p.L349V); biallelic } \\
\text { CEBPA mutated AML: } \\
\text { 20\%-39\% and } \\
\text { located in N-terminal } \\
\text { ZF }\end{array}$ & $\begin{array}{l}\text { MDS: }<5 \% \\
\text { AML: }<1 \%\end{array}$ & $\begin{array}{l}\text { No clear impact on } \\
\text { outcome other than } \\
\text { adverse effect of inv( } 3 \text { ) } \\
\text { translocation that brings } \\
\text { GATA2 enhancer ("-77") } \\
\text { near EVI1 in MDS/AML }\end{array}$ & $\begin{array}{c}1,25,62-64,67 \\
68,73,74,186\end{array}$ \\
\hline RUNX1 & $\begin{array}{l}\text { Embryonic lethal; defective fetal } \\
\text { liver hematopoiesis }\end{array}$ & $\begin{array}{l}\text { Truncations and large } \\
\text { deletions (70\%); missenses } \\
\text { cluster in RUNT domain; } \\
\text { complex 21q abnormalities }\end{array}$ & MDS/AML: unknown & $\begin{array}{c}\text { B cell ALL: } \\
\text { translocations, } \\
\text { amplifications; MDS: } \\
\text { missense, truncating; } \\
\text { AML: translocations, } \\
\text { missense, truncating }\end{array}$ & $\begin{array}{l}\text { B cell ALL: ETV6-RUNX1 } \\
\text { in 22\%; MDS: 10\%- } \\
\text { 15\%; AML: 7\%-9\% } \\
\text { including RUNX1- } \\
\text { RUNX1T1 in 5\% }\end{array}$ & $\begin{array}{l}1 \text { B cell ALL: favorable } \\
\text { prognosis with ETV6- } \\
\text { RUNX1 translocation; } \\
\text { MDS: adverse; AML: } \\
\text { favorable with RUNX1- } \\
\text { RUNX1T1 translocation; } \\
\text { inconclusive with other } \\
\text { RUNX1 abnormalities }\end{array}$ & $\begin{array}{c}1,4,95-98 \\
118-120,186 \\
187,195\end{array}$ \\
\hline ETV6 & $\begin{array}{c}\text { Embryonic lethal; lack of all } \\
\text { hematopoietic lineages if } \\
\text { absent in bone marrow }\end{array}$ & $\begin{array}{l}\text { Missenses most common } \\
\text { with majority in ETS domain } \\
\text { and } 1 \text { recurrent mutation at } \\
\text { p.P214L in linker domain; } \\
\text { truncations throughout } \\
\text { the gene }\end{array}$ & $\begin{array}{l}\text { Childhood ALL: } \\
0.8 \% \text {; inherited } \\
\text { thrombocytopenia: } \\
\text { 2.6\% }\end{array}$ & $\begin{array}{c}\text { B cell ALL: } \\
\text { translocations most } \\
\text { common; MDS: } \\
\text { missenses, truncating; } \\
\text { AML: translocations, } \\
\text { missenses, and } \\
\text { truncating }\end{array}$ & $\begin{array}{l}\text { B cell ALL: ETV6-RUNX1 } \\
\text { in } 22 \% \text {; MDS: } 3 \% \text {; } \\
\text { AML: } 1 \%\end{array}$ & $\begin{array}{l}1 \text { B cell ALL: favorable } \\
\text { prognosis with ETV6- } \\
\text { RUNX1 translocation; } \\
\text { MDS: adverse }\end{array}$ & $\begin{array}{c}1,136-140 \\
149-155 \\
185-188,195\end{array}$ \\
\hline IKZFI & $\begin{array}{l}\text { B cell, T cell, erythroid, } \\
\text { and myeloid deficits }\end{array}$ & $\begin{array}{l}\text { Missenses throughout } \\
\text { gene (majority); truncating } \\
\text { throughout gene; large } \\
\text { deletions }\end{array}$ & $\begin{array}{c}\text { Childhood B cell ALL: } \\
0.9 \%\end{array}$ & $\begin{array}{l}\text { B cell ALL: deletions } \\
\text { most common } \\
\text { (isoforms with } \\
\text { exons 4-7del have } \\
\text { dominant-negative } \\
\text { activity whereas } \\
\text { larger deletions are } \\
\text { haploinsufficient); } \\
\text { truncations and } \\
\text { missenses less } \\
\text { common }\end{array}$ & $\begin{array}{c}\text { T cell ALL: } 4 \% \text {; B } \\
\text { cell ALL: } 20 \%-30 \% \\
\text { (includes } 3 \% \text { of ETV6- } \\
\text { RUNX1 translocated } \\
\text { cases and } 70 \% \text { of } B C R \text { - } \\
\text { ABL or BCR-ABL-like } \\
\text { ALL) }\end{array}$ & Adverse & 189-193 \\
\hline PAX5 & $\begin{array}{l}\text { B cells arrested at } \\
\text { pro-B cell stage }\end{array}$ & p.G183S & 2 Families & $\begin{array}{l}\text { B cell ALL: deletions } \\
\text { most common; } \\
\text { missenses (including } \\
\text { p.G183S), truncations } \\
\text { throughout the gene, } \\
\text { and rearrangements } \\
\text { less common }\end{array}$ & B cell ALL: 30\% & $\begin{array}{l}\text { No clear impact on } \\
\text { outcome }\end{array}$ & 192, 194-197 \\
\hline
\end{tabular}

Transcript numbers: CEBPA, NM_004364; GATA-2, NM_032638; RUNX1, NM_001754; ETV6, NM_001987; IKZF1, NM_006060; PAX5, NM_016734.

emergence and function (Figure 1). In support of this model, GATA-2 $(106,107)$ and RUNX1 $(108,109)$ control megakaryopoiesis, and disrupted megakaryopoiesis and atypical megakaryocytes are hallmarks of GATA-2- and RUNX1-linked pathologies $(4,70)$.

Conditional Runx1 deletion studies identified PU.1, another ETS-family transcription factor, as a major component of the
RUNX1-regulated genetic network (110). Restoration of PU.1 expression in Runx1-knockout mice or mice with mutations in PU.1 upstream regulatory elements where RUNX1 binds can partially or fully rescue hematopoietic defects in either system. Expression profiling of patient platelets containing a heterozygous RUNX1 mutation revealed the downregulation of direct RUNX1 
target genes including 12-lipoxygenase ( $A L O X 12)$, platelet myosin light chain (MYL9), pallidin (PLDN), and thrombopoietin receptor $(M P L)(111)$. These genes are involved in diverse platelet pathways, mirroring human FPDMM platelet abnormalities, including decreased platelet aggregation and ATP secretion in response to agonists, dense and $\alpha$-granule deficiencies, and decreased platelet thrombopoietin receptors (112).

RUNX1 occupies target sites in the 5'-UTR of ANKRD26, which encodes an ankyrin repeat protein that associates with the inner cell membrane and is expressed in many tissues, including brain, liver, and adipose tissue, and the hematopoietic system (113). Homozygous mutation of murine Ankrd26 causes massive obesity, insulin resistance, and large body size. In humans, mutations that cluster in a 22-nucleotide region of the 5 -UTR of ANKRD26 cause THC2 syndrome, a familial thrombocytopenia and hematologic malignancy syndrome that is strikingly similar to FPDMM and lacks the murine obesity phenotype (114-116). Studies in human megakaryocytes revealed that these 5'-UTR mutations occur at RUNX1 binding sites, where RUNX1 and the ETS factor FLI1 function to suppress ANKRD26 expression. RUNX1/ FLI1 failure to bind these sites led to increased thrombopoietin, MAPK and ERK signaling, and defective proplatelet formation (117). As expected, ANKRD26 expression is elevated in FPDMM patient platelets with RUNX1 mutations, implicating this network in the thrombocytopenia of both disorders.

RUNX1 dysfunction in human pathologies. Heterozygous RUNX1 germline mutations cause FPDMM, featuring platelet dysfunction, thrombocytopenia, and hematopoietic malignancy predisposition (Table 3) (4). As with GATA-2 deficiency syndrome, even thrombocytopenia in FPDMM is incompletely penetrant, with a subset of affected individuals displaying normal platelet counts throughout their lifespan $(118,119)$. This suggests that a single RUNX1 allele can support thrombopoiesis, and other factors contribute to this disease phenotype and MDS/AML progression.

In FPDMM, truncating mutations, including nonsense, frameshift, splice-site, as well as large deletions, occur throughout $R U N X 1$ and account for the majority (70\%) of reported mutations (Table 4).RUNX1 loss due to whole gene deletions alone or as part of larger, multigenic abnormalities on chromosome 21q in the context of additional syndromic features such as intellectual disability are also seen (118). Missense mutations clustering in the RUNT domain, especially at sites p.R201 and p.R204, are also common. Whereas the nonsense and deletion mutations decrease protein levels, some missense mutations generate mutant proteins that retain CBF- $\beta$ dimerization, but are DNA binding-defective (93, 120) and dominant-negative inhibitors in vitro (120). An association between carrying a mutation that generates dominantnegative activity in vitro and a higher proportion of individuals developing leukemia has been described (120); however, larger cohorts need to be analyzed.

As with GATA2, whether diverse insults or a predominant genetic or environmental insult triggers the transition to MDS/ AML in FPDMM remains unresolved. Analyses of somatic events occurring before MDS/AML development in FPDMM have begun to yield insights. In a small FPDMM cohort, $67 \%$ of asymptomatic patients younger than 50 years old displayed clonal hematopoiesis in PB (77). This is remarkably higher than the less than $1 \%$ frequency expected in the general population (121-123), suggesting a baseline increase in mutagenic events in FPDMM HSPCs. Although the mechanistic underpinnings of this observation are unknown, the RUNX1 link to DNA repair pathways (e.g., RUNX1 interacts with the homologous recombination pathway component FANCD2; ref. 124) necessitates future investigation.

In FPDMM, the age of onset of hematologic malignancy development is a median 33 years but ranges widely (5-79 years) (Table 3). MDS and AML occur most frequently, although T cell acute lymphoblastic leukemia (ALL), non-Hodgkin lymphoma, and other lymphoid malignancies have been observed (125). At the onset of MDS/AML, loss of the normal RUNX1 allele and acquisition of various chromosomal abnormalities have been described (126). Somatic mutations in the cell cycle-regulatory phosphatase CDC25C were detected in $53 \%$ of a small Japanese RUNX1 mutant cohort with FPDMM (127), but these were not detected in French or American studies $(77,128)$. Acquired mutations in other genes, e.g., PDS5B, TET2, PHF6, and DNMT3A, have been detected in individual cases $(77,129)$. It will be important to elucidate global RUNX1-dependent genetic networks and functional circuits, as the deleterious consequences of target gene alterations often remain elusive when the focus is on individual genes. As GATA-2 activates Runx1 transcription, and at least certain GATA-2 and RUNX1 target genes overlap, the integrated GATA-2/RUNX1 network constitutes an invaluable resource for establishing whether pathogenic network perturbations are highly specific, or whether any deviation from the physiological network promotes the transition of benign hematologic disorders to malignancy.

\section{Thrombocytopenia 5 (THC5)}

Mechanistic foundations. ETV6, formerly termed TEL (translocation-ETS-leukemia) (130), is an ETS transcription factor (131) identified from its frequent involvement in leukemogenic translocations that yield fusion proteins. RUNX1 (132) is one of numerous ETV6 fusion partners (130, 133-135). Targeted deletion of murine Etv6 is embryonic lethal and disrupts yolk sac angiogenesis (136). While analysis of ETV6 function in adult mice via embryonic stem cell aggregation chimeras revealed it to be dispensable for yolk sac and fetal liver hematopoiesis (137), it was essential for BM hematopoiesis, providing an example of a transcription factor required in one hematopoietic compartment and not others. Conditional deletion studies confirmed an ETV6 requirement for BM HSC survival (138).

Contrasting with other ETS transcription factors that activate genes (131), ETV6 has been reported to function predominantly as a transcriptional repressor (139-141). ETV6 harbors an N-terminal helix-loop-helix domain, also deemed a "pointed" or sterile $\alpha$ motif (SAM) domain, that mediates dimerization and repression (142-145). This domain distinguishes ETV6 from most ETS factors, which lack this domain, and serves as a corepressor docking site $(141,142)$. An autoinhibitory domain ("linker region"), residing between the SAM domain and the C-terminal DNA-binding domain (146), restricts ETV6 DNA binding. This autoinhibitory mechanism is opposed by ETV6 self-association, which facilitates DNA binding to sites containing multiple ETS motifs (146-148).

ETV6 dysfunction in human pathologies. The majority of the heterozygous germline ETV6 mutations reported are mis- 
sense mutations within the C-terminal DNA-binding domain (Table 4) (149-153). One linker region mutation, p.P214L, is also recurrent $(152,154)$. Rare truncating or missense mutations outside the DNA-binding and linker domains have been reported. These mutations decrease ETV6 nuclear localization, DNA binding, and/or transcriptional repression $(149,155)$, and certain mutants exhibit dominant-negative activity in vitro. All of the mutations disrupt ETV6-mediated repression and ETV6dependent genetic networks.

Nearly $100 \%$ of affected individuals with THC5 described to date have thrombocytopenia, with a mean observed platelet count of 86 (149-155), suggesting that a single copy of ETV6 is insufficient for normal platelet development. In vitro cultures of patient-derived ETV6 mutant megakaryocytes revealed proplatelet maturation deficits and decreased polyploidization (Table 3) (155), supporting this hypothesis. In contrast with the diverse platelet pathologies of FPDMM, THC5 platelets exhibit only mild, inconsistent defects in platelet aggregation studies in vitro, and granule deficiencies have not been reported (155), suggesting quantitative and/or qualitative differences in the consequences of ETV6 and RUNX1 mutations in megakaryocytes.

As with FPDMM and GATA-2 deficiency syndrome, hematologic malignancies occur only in a subset, suggesting that the germline ETV6 mutation alone is insufficient for transformation to malignancy and likely requires additional genomic or environmental insults (Table 3). Individuals with THC5 can have an increased number of circulating $\mathrm{CD}_{3} 4^{+}$hematopoietic progenitors in PB (153), suggesting a potential role for ETV6 in HSC/ $\mathrm{BM}$ niche interactions in this pathophysiology. Among the $25 \%-$ $39 \%$ of THC5 mutation carriers reported who progressed to develop a hematologic malignancy (149-151, 153-155), childhood-onset ALL has been the most frequently occurring hematopoietic malignancy. Subsequently, rare, germline ETV6 variants were identified in $1 \%$ (31 of 4,405$)$ of unselected children with ALL and were associated with an older age at ALL diagnosis (10vs.5years, $P=0.02$ ) and ahyperdiploid karyotype (64\% vs.27\%, $P<0.01)$ (152), suggesting a larger role for ETV6 germline variation in ALL risk. Biphenotypic acute leukemia, MDS, AML, and polycythemia vera have also been observed in THC5, reflecting ETV6 activity to regulate myeloid development as well (149-151). Considering ETV6 function in BM hematopoiesis, it is unclear why heterozygous ETV6 dysregulation predominantly predisposes to ALL. Furthermore, the cooperating genomic lesions that cause ALL versus myeloid malignancy progression are not established.

\section{Familial AML due to germline CEBPA mutation}

Mechanistic foundations. $\mathrm{C} / \mathrm{EBP} \alpha$ is a basic leucine zipper (bZip) transcription factor that has been studied extensively in diverse systems. C/EBP $\alpha$ contains a leucine zipper that forms an amphipathic $\alpha$ helix that combines with the leucine zipper on a partner protein to mediate dimerization (156-158). The C/EBP $\alpha$ basic region contains DNA-binding specificity and affinity determinants (159). Since C/EBP $\alpha$ binds DNA as a homo- or heterodimer, by mediating dimerization, the leucine zipper domain indirectly confers DNA binding. This concept is exemplified by a leucine zipper swap in which leucine zippers from proteins with distinct DNA-binding specificities (e.g., C/EBP $\alpha$ and GCN4) are exchanged, preserving dimerization and the DNA-binding specificity imparted by the respective basic region (160).

Targeted ablation of murine Cebpa is lethal several hours after birth and is characterized by severe dysregulation of liver metabolic processes (161). From a hematopoietic perspective, Cebpa homozygous mutant mice are defective in granulopoiesis, but not other hematopoietic processes (162), highlighting its lineage specificity. RUNX1 induces C/EBP $\alpha$ expression, which inhibits myeloproliferation and promotes granulocytic differentiation. Lack of $\mathrm{C} / \mathrm{EBP} \alpha$ expression is an important component of the myeloproliferative phenotype of Runx1 mutant mice (163).

CEBPA dysfunction in human pathologies. Acquired CEBPA mutations occur in $6 \%-9 \%$ of adult-onset AML cases (Table 4) $(1,164)$ and generate mutant proteins with or without dominantnegative activity (165-169). Approximately 5\%-11\% of these patients carry one of the detected mutations in the germline (170). In acquired and germline settings, the majority of causative CEBPA mutations are frameshifts occurring $5^{\prime}$ to a second transcriptional start site encoding a shorter isoform (p30) (171-173). These mutations reduce expression of full-length $\mathrm{C} / \mathrm{EBP} \alpha$ (p42 isoform) and increase expression of a dominant-negative isoform (p30), diminishing p42 availability to promote differentiation and cell cycle arrest $(169,174)$. Among germline cases at the time of AML development and AML cases with acquired biallelic mutations, nearly all cases have acquired a second CEBPA mutation on the previously normal allele, commonly disrupting the $\mathrm{C} / \mathrm{EBP} \alpha \mathrm{C}$-terminal leucine zipper. Rare families with germline missense mutations disrupting the leucine zipper have been reported $(175,176)$.

Germline upstream frameshift versus leucine zipper missense mutations appear to differ in expected penetrance, highlighting differences in biologic mechanisms. Whereas approximately $100 \%$ of those carrying an upstream frameshift are expected to develop AML, a lower proportion of those with distal leucine zipper mutations develop AML (estimated at $45 \%)(171,176)$. These differences closely parallel findings in model systems. Whereas mice with a heterozygous upstream frameshift do not develop overt AML, mice with biallelic frameshifts develop AML with $100 \%$ penetrance and more rapidly than mice carrying biallelic distal leucine zipper mutations $(174,177)$. Mice with both an upstream frameshift and a distal leucine zipper mutant allele develop AML the fastest, suggesting a synergism that explains the observed pattern in germline and sporadic CEBPA-mutated cases described above $(164,178,179)$.

As with the other MDS/AML predisposition syndromes described, the single germline CEBPA mutation alone appears to be insufficient to induce AML. Individuals in the dozen or so pedigrees reported with a germline $C E B P A$ mutation are clinically normal until the emergence of AML (180). The AML phenotype is uniform across pedigrees, usually featuring a French-American-British M1, M2, or M4 morphology with abnormal eosinophils and a normal karyotype (171). In addition to the uniform acquisition of a second CEBPA mutation, GATA2, WT1, and EZH2 mutations are the most frequent co-occurring mutations acquired at the time of AML (171). This uniform AML phenotype differs from the diverse hematologic malignancies seen in GATA-2 deficiency syndrome, FPDMM, and THC5, and parallels the more lineage-restricted phenotypes of $\mathrm{C} /$ 
$\mathrm{EBP} \alpha$ dysregulation, rather than the broader spectrum of hematopoietic-regulatory activities of GATA-2, RUNX1, or ETV6.

AML prognosis in these cases is favorable and similar to that of sporadic AML featuring biallelic acquired CEBPA mutations (171). However, later relapses involving leukemic clones molecularly independent of the initial leukemic presentation and more favorable postrelapse survival characterize familial in comparison with sporadic cases (171), suggesting that these are actually de novo AML episodes arising from a leukemia-prone HSC pool in germline CEBPA mutation carriers. The exact mechanisms favoring acquisition of the second CEBPA mutation or other cooperating genomic lesions remain unknown, and elucidating these mechanisms is critical to facilitate progress in preventing AML in individuals with this syndrome.

\section{Summary}

Next-generation sequencing has revealed that germline mutations predisposing to MDS/AML are considerably more common than previously thought. Analyses of these mutations in genes encoding transcription factors continue to unveil mechanistic insights that may provide new avenues for innovating much-sought-after molecularly targeted therapies. The transcription factors described herein exhibit varying degrees of mechanistic overlap. A factor can regulate expression of the other, and multiple factors expressed at the same time and in the same cell can function collectively in heteromeric complexes at target genes. Genetic networks established and maintained by these factors are still being discovered. While it is relatively straightforward to conduct transcriptional profiling to tabulate gene expression changes resulting from a given transcription factor perturbation, now even at the single-cell level, it is highly challenging to integrate this rudimentary information with other -omic data sets to yield a lucid view of the regulatory networks. Furthermore, new approaches are required to decipher functionally critical circuits within the networks and elucidate how altering the expression and activity of components within these circuits impacts cell function. It would not be surprising if MDS/ AML resulting from germline mutations of transcription factorencoding genes involves a multitude of perturbations of network components to yield a spectrum of disease phenotypes with implications for precision medicine therapeutics.
Multidisciplinary studies with large patient cohorts and diverse models are required to forge principles to understand the complex path from germline mutation to benign pathology to MDS/AML. In contrast to the opportunity for large-scale clinical studies with somatic mutants, germline mutations are considerably less frequent, and international collaboration is vital to achieve analytical power. The propensity for germline mutations to generate a predisposition or to induce disease may vary in different populations owing to additional genetic and/or environmental parameters. It will be crucial to forge new systems that enable the discovery of disease triggers, as well as disease suppressors. Identifying aberrant networks, triggers, and suppressors may catalyze the development of therapeutic alternatives to HSC transplantation. The momentum in gene-editing technologies may ultimately benefit those with germline mutation-linked disease. Though efforts have begun to correct genetic defects in patient-derived inducedpluripotent cells $(181,182)$, the path to rigorously gauge utility, safety, and broad applicability of this strategy will require intense efforts and considerable perseverance. Leveraging mechanistic insights involving aberrant networks and circuits to develop normalization therapies, to repress mutant allele expression, or to elevate wildtype allele expression constitutes a high-priority line of investigation that will translate into transformative clinical advances.

\section{Acknowledgments}

We thank Kirby Johnson, Koichi Katsumura, and Charu Mehta for comments on the manuscript. We apologize to our colleagues whose work we could not discuss owing to space limitations. EHB acknowledges support from the NIH (DK50107 and DK68634), Carbone Cancer Center (P30CA014520), Evans Foundation, and Midwest Athletes Against Childhood Cancer. JEC acknowledges support from the NIH (NHLBI K08 HL129088 and R03 HL145253).

Address correspondence to: Jane E. Churpek, 5841 S. Maryland Avenue, MC2115, Chicago, IL 60637. Phone: 773.834.1076; Email: jchurpek@bsd.uchicago.edu. Or to: Emery H. Bresnick, University of Wisconsin School of Medicine and Public Health, Department of Cell and Regenerative Biology, 4009 WIMR, 1111 Highland Avenue, Madison, WI 53705. Phone: 608.513.9315; Email: ehbresni@wisc.edu.
1. Papaemmanuil E, et al. Genomic classification and prognosis in acute myeloid leukemia. $N$ Engl JMed. 2016;374(23):2209-2221.

2. Haferlach T, et al. Landscape of genetic lesions in 944 patients with myelodysplastic syndromes. Leukemia. 2014;28(2):241-247.

3. Mardis ER, et al. Recurring mutations found by sequencing an acute myeloid leukemia genome. N Engl J Med. 2009;361(11):1058-1066.

4. Song WJ, et al. Haploinsufficiency of CBFA2 causes familial thrombocytopenia with propensity to develop acute myelogenous leukaemia. Nat Genet. 1999;23(2):166-175.

5. Tawana K, Drazer MW, Churpek JE. Universal genetic testing for inherited susceptibility in children and adults with myelodysplastic syndrome and acute myeloid leukemia: are we there yet? Leukemia. 2018;32(7):1482-1492.
6. Bluteau $\mathrm{O}$, et al. A landscape of germ line mutations in a cohort of inherited bone marrow failure patients. Blood. 2018;131(7):717-732.

7. Godley LA, Shimamura A. Genetic predisposition to hematologic malignancies: management and surveillance. Blood. 2017;130(4):424-432.

8. Ostergaard P, et al. Mutations in GATA2 cause primary lymphedema associated with a predisposition to acute myeloid leukemia (Emberger syndrome). Nat Genet. 2011;43(10):929-931.

9. Hahn CN, et al. Heritable GATA2 mutations associated with familial myelodysplastic syndrome and acute myeloid leukemia. Nat Genet. 2011;43(10):1012-1017.

10. Dickinson RE, et al. Exome sequencing identifies GATA-2 mutation as the cause of dendritic cell, monocyte, B and NK lymphoid deficiency. Blood. 2011;118(10):2656-2658.
11. Hsu AP, et al. Mutations in GATA2 are associated with the autosomal dominant and sporadic monocytopenia and mycobacterial infection (MonoMAC) syndrome. Blood. 2011;118(10):2653-2655.

12. Johnson $\mathrm{KD}$, et al. Cis-element mutated in GATA2-dependent immunodeficiency governs hematopoiesis and vascular integrity. JClin Invest. 2012;122(10):3692-3704.

13. Hsu AP, et al. GATA2 haploinsufficiency caused by mutations in a conserved intronic element leads to MonoMAC syndrome. Blood. 2013;121(19):3830-3837, S1.

14. Katsumura KR, Bresnick EH, GATA Factor Mechanisms Group. The GATA factor revolution in hematology. Blood. 2017;129(15):2092-2102.

15. Bresnick EH, Katsumura KR, Lee HY, Johnson KD, Perkins AS. Master regulatory GATA tran- 
scription factors: mechanistic principles and emerging links to hematologic malignancies. Nucleic Acids Res. 2012;40(13):5819-5831.

16. Evans T, Felsenfeld G. The erythroid-specific transcription factor Eryf1: a new finger protein. Cell. 1989;58(5):877-885.

17. Tsai SF, Martin DI, Zon LI, D’Andrea AD, Wong GG, Orkin SH. Cloning of cDNA for the major DNA-binding protein of the erythroid lineage through expression in mammalian cells. Nature. 1989;339(6224):446-451.

18. Merika M, Orkin SH. DNA-binding specificity of GATA family transcription factors. Mol Cell Biol. 1993;13(7):3999-4010.

19. Ko LJ, Engel JD. DNA-binding specificities of the GATA transcription factor family. Mol Cell Biol. 1993;13(7):4011-4022.

20. Fujiwara T, et al. Discovering hematopoietic mechanisms through genome-wide analysis of GATA factor chromatin occupancy. Mol Cell. 2009;36(4):667-681.

21. Pevny L, et al. Erythroid differentiation in chimaeric mice blocked by a targeted mutation in the gene for transcription factor GATA-1. Nature. 1991;349(6306):257-260.

22. Shivdasani RA, Fujiwara Y, McDevitt MA, Orkin SH. A lineage-selective knockout establishes the critical role of transcription factor GATA-1 in megakaryocyte growth and platelet development. ЕMBO J.1997;16(13):3965-3973.

23. Yu C, et al. Targeted deletion of a high-affinity GATA-binding site in the GATA-1 promoter leads to selective loss of the eosinophil lineage in vivo. JExp Med. 2002;195(11):1387-1395.

24. Nei Y, et al. GATA-1 regulates the generation and function of basophils. Proc Natl Acad Sci U S A. 2013;110(46):18620-18625.

25. Tsai FY, et al. An early haematopoietic defect in mice lacking the transcription factor GATA-2. Nature. 1994;371(6494):221-226.

26. Ling KW, et al. GATA-2 plays two functionally distinct roles during the ontogeny of hematopoietic stem cells. JExp Med. 2004;200(7):871-882.

27. Rodrigues NP, et al. Haploinsufficiency of GATA-2 perturbs adult hematopoietic stem-cell homeostasis. Blood. 2005;106(2):477-484.

28. Gao X, et al. Gata2 cis-element is required for hematopoietic stem cell generation in the mammalian embryo. J Exp Med. 2013;210(13):2833-2842.

29. Johnson KD, et al. Cis-regulatory mechanisms governing stem and progenitor cell transitions. Sci Adv. 2015;1(8):e1500503.

30. Lim KC, et al. Conditional Gata2 inactivation results in HSC loss and lymphatic mispatterning. JClin Invest. 2012;122(10):3705-3717.

31. de Pater E, et al. Gata2 is required for HSC generation and survival. J Exp Med. 2013;210(13):2843-2850.

32. Hewitt KJ, et al. Hematopoietic signaling mechanism revealed from a stem/progenitor cell cistrome. Mol Cell. 2015;59(1):62-74.

33. Fujiwara T, Lee HY, Sanalkumar R, Bresnick EH. Building multifunctionality into a complex containing master regulators of hematopoiesis. Proc Natl Acad Sci U S A. 2010;107(47):20429-20434.

34. Lurie LJ, Boyer ME, Grass JA, Bresnick EH. Differential GATA factor stabilities: implications for chro- matin occupancy by structurally similar transcription factors. Biochemistry. 2008;47(3):859-869.

35. Minegishi N, Suzuki N, Kawatani Y, Shimizu R, Yamamoto M. Rapid turnover of GATA-2 via ubiquitin-proteasome protein degradation pathway. Genes Cells. 2005;10(7):693-704.

36. Friedle H, Knöchel W. Cooperative interaction of Xvent-2 and GATA- 2 in the activation of the ventral homeobox gene Xvent-1B. J Biol Chem. 2002;277(26):23872-23881.

37. Lugus JJ, et al. GATA2 functions at multiple steps in hemangioblast development and differentiation. Development. 2007;134(2):393-405.

38. Lee D, et al. ER71 acts downstream of BMP, Notch, and Wnt signaling in blood and vessel progenitor specification. Cell Stem Cell. 2008;2(5):497-507.

39. Xu CX, et al. ETV2/ER71 regulates hematopoietic regeneration by promoting hematopoietic stem cell proliferation.JExp Med. 2017;214(6):1643-1653.

40. Park C, et al. Injury-mediated vascular regeneration requires endothelial ER71/ETV2. Arterioscler Thromb Vasc Biol. 2016;36(1):86-96.

41. Liu F, et al. Induction of hematopoietic and endothelial cell program orchestrated by ETS transcription factor ER71/ETV2. EMBO Rep. 2015;16(5):654-669.

42. Bresnick EH, Lee HY, Fujiwara T, Johnson KD, Keles S. GATA switches as developmental drivers. J Biol Chem. 2010;285(41):31087-31093.

43. Grass JA, Boyer ME, Pal S, Wu J, Weiss MJ, Bresnick EH. GATA-1-dependent transcriptional repression of GATA-2 via disruption of positive autoregulation and domain-wide chromatin remodeling. Proc Natl Acad Sci U S A. 2003;100(15):8811-8816.

44. Wozniak RJ, Boyer ME, Grass JA, Lee Y, Bresnick EH. Context-dependent GATA factor function: combinatorial requirements for transcriptional control in hematopoietic and endothelial cells. J Biol Chem. 2007;282(19):14665-14674.

45. Martowicz ML, Grass JA, Boyer ME, Guend H, Bresnick EH. Dynamic GATA factor interplay at a multicomponent regulatory region of the GATA-2 locus. J Biol Chem. 2005;280(3):1724-1732.

46. Grass JA, et al. Distinct functions of dispersed GATA factor complexes at an endogenous gene locus. Mol Cell Biol. 2006;26(19):7056-7067.

47. Sanalkumar R, et al. Mechanism governing a stem cell-generating cis-regulatory element. Proc Natl Acad Sci U S A. 2014;111(12):E1091-E1100.

48. Snow JW, et al. Context-dependent function of "GATA switch" sites in vivo. Blood. 2011;117(18):4769-4772.

49. Snow JW, et al. A single cis element maintains repression of the key developmental regulator Gata2. PLoS Genet. 2010;6(9):e1001103.

50. Mehta C, et al. Integrating enhancer mechanisms to establish a hierarchical blood development program. Cell Rep. 2017;20(12):2966-2979.

51. Linnemann AK, O'Geen H, Keles S, Farnham PJ, Bresnick EH. Genetic framework for GATA factor function in vascular biology. Proc Natl Acad Sci U S A. 2011;108(33):13641-13646.

52. Munugalavadla V, et al. Repression of c-kit and its downstream substrates by GATA-1 inhibits cell proliferation during erythroid maturation. $\mathrm{Mol}$ Cell Biol. 2005;25(15):6747-6759.
53. Jing H, et al. Exchange of GATA factors mediates transitions in looped chromatin organization at a developmentally regulated gene locus. Mol Cell. 2008;29(2):232-242.

54. McIver SC, et al. Exosome complex orchestrates developmental signaling to balance proliferation and differentiation during erythropoiesis. Elife. 2016;5:e17877.

55. Crispino JD, Lodish MB, MacKay JP, Orkin SH. Use of altered specificity mutants to probe a specific protein-protein interaction in differentiation: the GATA-1:FOG complex. Mol Cell. 1999;3(2):219-228.

56. Bresnick EH, Hewitt KJ, Mehta C, Keles S, Paulson RF, Johnson KD. Mechanisms of erythrocyte development and regeneration: implications for regenerative medicine and beyond. Development. 2018;145(1):dev151423.

57. Pal S, et al. Coregulator-dependent facilitation of chromatin occupancy by GATA-1. Proc Natl Acad SciU S A. 2004;101(4):980-985.

58. Gao X, et al. GATA factor-G-protein-coupled receptor circuit suppresses hematopoiesis. Stem Cell Reports. 2016;6(3):368-382.

59. Hoang T, Lambert JA, Martin R. SCL/TAL1 in hematopoiesis and cellular reprogramming. Curr Top Dev Biol. 2016;118:163-204.

60. Phelan JD, Shroyer NF, Cook T, Gebelein B, Grimes HL. Gfi1-cells and circuits: unraveling transcriptional networks of development and disease. Curr Opin Hematol. 2010;17(4):300-307.

61. Wilkinson AC, Nakauchi H, Göttgens B. Mammalian transcription factor networks: recent advances in interrogating biological complexity. Cell Syst. 2017;5(4):319-331.

62. Zhang SJ, et al. Gain-of-function mutation of GATA-2 in acute myeloid transformation of chronic myeloid leukemia. Proc Natl Acad Sci U S A. 2008;105(6):2076-2081.

63. Zhang SJ, Shi JY, Li JY. GATA-2 L359 V mutation is exclusively associated with CML progression but not other hematological malignancies and GATA-2 P250A is a novel single nucleotide polymorphism. Leuk Res. 2009;33(8):1141-1143.

64. Greif PA, et al. GATA2 zinc finger 1 mutations associated with biallelic CEBPA mutations define a unique genetic entity of acute myeloid leukemia. Blood. 2012;120(2):395-403.

65. Pedone PV, et al. The N-terminal fingers of chicken GATA-2 and GATA-3 are independent sequence-specific DNA binding domains. EMBO J. 1997;16(10):2874-2882.

66. Calvo KR, et al. Myelodysplasia in autosomal dominant and sporadic monocytopenia immunodeficiency syndrome: diagnostic features and clinical implications. Haematologica. 2011;96(8):1221-1225.

67. Pasquet M, et al. High frequency of GATA2 mutations in patients with mild chronic neutropenia evolving to MonoMac syndrome, myelodysplasia, and acute myeloid leukemia. Blood. 2013;121(5):822-829.

68. Wlodarski MW, et al. Prevalence, clinical characteristics, and prognosis of GATA2-related myelodysplastic syndromes in children and adolescents. Blood. 2016;127(11):1387-1397.

69. Keel SB, et al. Genetic features of myelodysplastic syndrome and aplastic anemia in pedi- 
atric and young adult patients. Haematologica. 2016;101(11):1343-1350.

70. Ganapathi KA, et al. GATA2 deficiency-associated bone marrow disorder differs from idiopathic aplastic anemia. Blood. 2015;125(1):56-70.

71. McReynolds LJ, Calvo KR, Holland SM. Germline GATA2 mutation and bone marrow failure. Hematol Oncol Clin North Am. 2018;32(4):713-728.

72. Dickinson RE, et al. The evolution of cellular deficiency in GATA2 mutation. Blood. 2014;123(6):863-874.

73. Donadieu J, et al. Natural history of GATA2 deficiency in a survey of 79 French and Belgian patients. Haematologica. 2018;103(8):1278-1287.

74. Spinner MA, et al. GATA2 deficiency: a protean disorder of hematopoiesis, lymphatics, and immunity. Blood. 2014;123(6):809-821.

75. Bödör C, et al. Germ-line GATA2 p.THR354MET mutation in familial myelodysplastic syndrome with acquired monosomy 7 and ASXL1 mutation demonstrating rapid onset and poor survival. Haematologica. 2012;97(6):890-894.

76. West RR, Hsu AP, Holland SM, CuellarRodriguez J, Hickstein DD. Acquired ASXL1 mutations are common in patients with inherited GATA2 mutations and correlate with myeloid transformation. Haematologica. 2014;99(2):276-281.

77. Churpek JE, et al. Genomic analysis of germ line and somatic variants in familial myelodysplasia/acute myeloid leukemia. Blood. 2015;126(22):2484-2490.

78. Micol JB, Abdel-Wahab O. Collaborating constitutive and somatic genetic events in myeloid malignancies: ASXL1 mutations in patients with germline GATA2 mutations. Haematologica. 2014;99(2):201-203.

79. Al Seraihi AF, et al. GATA2 monoallelic expression underlies reduced penetrance in inherited GATA2-mutated MDS/AML. Leukemia. 2018;32(11):2502-2507.

80. Fisher KE, et al. Somatic mutations in children with GATA2-associated myelodysplastic syndrome who lack other features of GATA2 deficiency. Blood Adv. 2017;1(7):443-448.

81. Wozniak RJ, et al. Molecular hallmarks of endogenous chromatin complexes containing master regulators of hematopoiesis. Mol Cell Biol. 2008;28(21):6681-6694.

82. DeVilbiss AW, Sanalkumar R, Hall BD, Katsumura KR, de Andrade IF, Bresnick EH. Epigenetic determinants of erythropoiesis: role of the histone methyltransferase SetD8 in promoting erythroid cell maturation and survival. Mol Cell Biol. 2015;35(12):2073-2087.

83. Smale ST, Tarakhovsky A, Natoli G. Chromatin contributions to the regulation of innate immunity. Annu Rev Immunol. 2014;32:489-511.

84. Katsumura KR, et al. Human leukemia mutations corrupt but do not abrogate GATA-2 function. Proc Natl Acad Sci U S A. 2018;115(43):E10109-E10118.

85. Chong CE, et al. Differential effects on gene transcription and hematopoietic differentiation correlate with GATA2 mutant disease phenotypes. Leukemia. 2018;32(1):194-202.

86. Kazenwadel J, et al. Loss-of-function germline GATA2 mutations in patients with MDS/AML or
MonoMAC syndrome and primary lymphedema reveal a key role for GATA2 in the lymphatic vasculature. Blood. 2012;119(5):1283-1291.

87. Kazenwadel J, et al. GATA2 is required for lymphatic vessel valve development and maintenance. J Clin Invest. 2015;125(8):2979-2994.

88. Wigle JT, Oliver G. Prox1 function is required for the development of the murine lymphatic system. Cell. 1999;98(6):769-778.

89. Tijssen MR, et al. Genome-wide analysis of simultaneous GATA1/2, RUNX1, FLI1, and SCL binding in megakaryocytes identifies hematopoietic regulators. Dev Cell. 2011;20(5):597-609.

90. Melnikova IN, Crute BE, Wang S, Speck NA. Sequence specificity of the core-binding factor. J Virol.1993;67(4):2408-2411.

91. Kagoshima H, et al. The Runt domain identifies a new family of heteromeric transcriptional regulators. Trends Genet. 1993;9(10):338-341.

92. Zhang L, et al. Mutagenesis of the Runt domain defines two energetic hot spots for heterodimerization with the core binding factor beta subunit. J Biol Chem. 2003;278(35):33097-33104

93. Matheny CJ, et al. Disease mutations in RUNX1 and RUNX2 create nonfunctional, dominantnegative, or hypomorphic alleles. EMBOJ. 2007;26(4):1163-1175.

94. Tahirov TH, et al. Structural analyses of DNA recognition by the AML1/Runx-1 Runt domain and its allosteric control by CBFbeta. Cell. 2001;104(5):755-767.

95. Wang Q, et al. The CBFbeta subunit is essentia for CBFalpha2 (AML1) function in vivo. Cell. 1996;87(4):697-708.

96. Wang Q, Stacy T, Binder M, Marin-Padilla M, Sharpe AH, Speck NA. Disruption of the Cbfa2 gene causes necrosis and hemorrhaging in the central nervous system and blocks definitive hematopoiesis. Proc Natl Acad Sci U S A. 1996;93(8):3444-3449.

97. North T, et al. Cbfa2 is required for the formation of intra-aortic hematopoietic clusters. Development. 1999;126(11):2563-2575.

98. Okuda T, van Deursen J, Hiebert SW, Grosveld G, Downing JR. AML1, the target of multiple chromosomal translocations in human leukemia, is essential for normal fetal liver hematopoiesis. Cell. 1996;84(2):321-330.

99. Nottingham WT, et al. Runx1-mediated hematopoietic stem-cell emergence is controlled by a Gata/Ets/SCL-regulated enhancer. Blood. 2007;110(13):4188-4197.

100.Wilson NK, et al. Combinatorial transcriptional control in blood stem/progenitor cells: genomewide analysis of ten major transcriptional regulators. Cell Stem Cell. 2010;7(4):532-544.

101. Beck D, et al. Genome-wide analysis of transcriptional regulators in human HSPCs reveals a densely interconnected network of coding and noncoding genes. Blood. 2013;122(14):e12-e22.

102. Liakhovitskaia $A$, et al. Runx1 is required for progression of CD $41+$ embryonic precursors into HSCs but not prior to this. Development. 2014;141(17):3319-3323.

103. Chen MJ, Yokomizo T, Zeigler BM, Dzierzak E, Speck NA. Runx1 is required for the endothelial to haematopoietic cell transition but not thereafter. Nature. 2009;457(7231):887-891.
104. Tober J, Maijenburg MW, Speck NA. Taking the leap: Runx1 in the formation of blood from endothelium. Curr Top Dev Biol. 2016;118:113-162.

105. Lie-A-Ling M, et al. Regulation of RUNX1 dosage is crucial for efficient blood formation from hemogenic endothelium. Development. 2018;145(5):dev149419.

106.Chang AN, et al. GATA-factor dependence of the multitype zinc-finger protein FOG-1 for its essential role in megakaryopoiesis. Proc Natl Acad Sci US A. 2002;99(14):9237-9242.

107. Huang Z, et al. GATA-2 reinforces megakaryocyte development in the absence of GATA-1. Mol Cell Biol. 2009;29(18):5168-5180.

108. Ichikawa M, et al. AML-1 is required for megakaryocytic maturation and lymphocytic differentiation, but not for maintenance of hematopoietic stem cells in adult hematopoiesis. Nat Med. 2004;10(3):299-304.

109. Draper JE, et al. Mouse RUNX1C regulates premegakaryocytic/erythroid output and maintains survival of megakaryocyte progenitors. Blood. 2017;130(3):271-284.

110. Huang G, et al. PU.1 is a major downstream target of AML1 (RUNX1) in adult mouse hematopoiesis. Nat Genet. 2008;40(1):51-60.

111. Kaur G, Jalagadugula G, Mao G, Rao AK. RUNX1/core binding factor A2 regulates platelet 12-lipoxygenase gene (ALOX12): studies in human RUNX1 haplodeficiency. Blood. 2010;115(15):3128-3135.

112. Songdej N, Rao AK. Hematopoietic transcription factor mutations: important players in inherited platelet defects. Blood. 2017;129(21):2873-2881.

113. Bera TK, et al. A model for obesity and gigantism due to disruption of the Ankrd26 gene. Proc Natl Acad Sci U S A. 2008;105(1):270-275.

114. Pippucci T, et al. Mutations in the $5^{\prime}$ UTR of ANKRD26, the ankirin repeat domain 26 gene, cause an autosomal-dominant form of inherited thrombocytopenia, THC2. Am J Hum Genet. 2011;88(1):115-120.

115. Noris P, et al. ANKRD26-related thrombocytopenia and myeloid malignancies. Blood. 2013;122(11):1987-1989.

116. Noris P, et al. Mutations in ANKRD26 are responsible for a frequent form of inherited thrombocytopenia: analysis of 78 patients from 21 families. Blood. 2011;117(24):6673-6680.

117. Bluteau D, et al. Thrombocytopenia-associated mutations in the ANKRD26 regulatory region induce MAPK hyperactivation. JClin Invest. 2014;124(2):580-591.

118. Latger-Cannard V, et al. Haematological spectrum and genotype-phenotype correlations in nine unrelated families with RUNX1 mutations from the French network on inherited platelet disorders. Orphanet J Rare Dis. 2016;11:49.

119. Owen CJ, et al. Five new pedigrees with inherited RUNX1 mutations causing familial platelet disorder with propensity to myeloid malignancy. Blood. 2008;112(12):4639-4645.

120. Michaud J, et al. In vitro analyses of known and novel RUNX1/AML1 mutations in dominant familial platelet disorder with predisposition to acute myelogenous leukemia: implications for mechanisms of pathogenesis. Blood. 2002;99(4):1364-1372. 
121. Jaiswal S, et al. Age-related clonal hematopoiesis associated with adverse outcomes. N Engl J Med. 2014;371(26):2488-2498.

122.Xie M, et al. Age-related mutations associated with clonal hematopoietic expansion and malignancies. Nat Med. 2014;20(12):1472-1478.

123. Genovese G, et al. Clonal hematopoiesis and blood-cancer risk inferred from blood DNA sequence. N Engl J Med. 2014;371(26):2477-2487.

124.Wang CQ, et al. Disruption of Runx1 and Runx3 leads to bone marrow failure and leukemia predisposition due to transcriptional and DNA repair defects. Cell Rep. 2014;8(3):767-782.

125. Brown AL, Churpek JE, Malcovati L, Döhner H, Godley LA. Recognition of familial myeloid neoplasia in adults. Semin Hematol. 2017;54(2):60-68.

126. Preudhomme C, et al. High frequency of RUNX1 biallelic alteration in acute myeloid leukemia secondary to familial platelet disorder. Blood. 2009;113(22):5583-5587.

127. Yoshimi A, et al. Recurrent CDC25C mutations drive malignant transformation in FPD/AML. Nat Commun. 2014;5:4770.

128. Antony-Debré I, et al. Somatic mutations associated with leukemic progression of familial platelet disorder with predisposition to acute myeloid leukemia. Leukemia. 2016;30(4):999-1002.

129. Manchev VT, et al. Acquired TET2 mutation in one patient with familial platelet disorder with predisposition to AML led to the development of pre-leukaemic clone resulting in T2-ALL and AML-MO. J Cell Mol Med. 2017;21(6):1237-1242.

130. Golub TR, Barker GF, Lovett M, Gilliland DG. Fusion of PDGF receptor beta to a novel ets-like gene, tel, in chronic myelomonocytic leukemia with $\mathrm{t}(5 ; 12)$ chromosomal translocation. Cell. 1994;77(2):307-316.

131. Hollenhorst PC, McIntosh LP, Graves BJ. Genomic and biochemical insights into the specificity of ETS transcription factors. Annu Rev Biochem. 2011;80:437-471.

132. Golub TR, et al. Fusion of the TEL gene on 12 p13 to the AML1 gene on 21q22 in acute lymphoblastic leukemia. Proc Natl Acad Sci U S A. 1995;92(11):4917-4921.

133. Papadopoulos P, Ridge SA, Boucher CA, Stocking $\mathrm{C}$, Wiedemann LM. The novel activation of ABL by fusion to an ets-related gene, TEL. Cancer Res. 1995;55(1):34-38.

134. Odero MD, Carlson K, Calasanz MJ, Lahortiga I, Chinwalla V, Rowley JD. Identification of new translocations involving ETV6 in hematologic malignancies by fluorescence in situ hybridization and spectral karyotyping. Genes Chromosomes Cancer. 2001;31(2):134-142.

135. Wlodarska I, et al. Fluorescence in situ hybridization characterization of new translocations involving TEL (ETV6) in a wide spectrum of hematologic malignancies. Blood. 1998;91(4):1399-1406.

136. Wang LC, Kuo F, Fujiwara Y, Gilliland DG, Golub TR, Orkin SH. Yolk sac angiogenic defect and intra-embryonic apoptosis in mice lacking the Ets-related factor TEL. EMBO J. 1997;16(14):4374-4383.

137. Wang LC, et al. The TEL/ETV6 gene is required specifically for hematopoiesis in the bone mar- row. Genes Dev. 1998;12(15):2392-2402.

138. Hock H, et al. Tel/Etv6 is an essential and selective regulator of adult hematopoietic stem cell survival. Genes Dev. 2004;18(19):2336-2341.

139. Fears S, et al. Functional characterization of ETV6 and ETV6/CBFA2 in the regulation of the MCSFR proximal promoter. Proc Natl Acad Sci U S A. 1997;94(5):1949-1954.

140. Hiebert SW, et al. The t(12;21) translocation converts AML-1B from an activator to a repressor of transcription. Mol Cell Biol. 1996;16(4):1349-1355.

141. Lopez RG, Carron C, Oury C, Gardellin P, Bernard $\mathrm{O}$, Ghysdael J. TEL is a sequencespecific transcriptional repressor. J Biol Chem. 1999;274(42):30132-30138.

142. Fenrick R, et al. Both TEL and AML-1 contribute repression domains to the $\mathrm{t}(12 ; 21)$ fusion protein. Mol Cell Biol. 1999;19(10):6566-6574.

143. McLean TW, et al. TEL/AML-1 dimerizes and is associated with a favorable outcome in childhood acute lymphoblastic leukemia. Blood. 1996;88(11):4252-4258.

144.Kim CA, et al. Polymerization of the SAM domain of TEL in leukemogenesis and transcriptional repression. EMBO J. 2001;20(15):4173-4182.

145. Kim CA, Bowie JU. SAM domains: uniform structure, diversity of function. Trends Biochem Sci. 2003;28(12):625-628.

146.Green SM, Coyne HJ, McIntosh LP, Graves BJ. DNA binding by the ETS protein TEL (ETV6) is regulated by autoinhibition and self-association. J Biol Chem. 2010;285(24):18496-18504.

147. Coyne HJ, et al. Autoinhibition of ETV6 (TEL) DNA binding: appended helices sterically block the ETS domain. J Mol Biol. 2012;421(1):67-84.

148. De S, Okon M, Graves BJ, McIntosh LP. Autoinhibition of ETV6 DNA binding is established by the stability of its inhibitory helix. J Mol Biol. 2016;428(8):1515-1530.

149.Zhang MY, et al. Germline ETV6 mutations in familial thrombocytopenia and hematologic malignancy. Nat Genet. 2015;47(2):180-185.

150. Noetzli L, et al. Germline mutations in ETV6 are associated with thrombocytopenia, red cell macrocytosis and predisposition to lymphoblastic leukemia. Nat Genet. 2015;47(5):535-538.

151. Topka S, et al. Germline ETV6 mutations confer susceptibility to acute lymphoblastic leukemia and thrombocytopenia. PLoS Genet. 2015;11(6):e1005262.

152. Moriyama T, et al. Germline genetic variation in ETV6 and risk of childhood acute lymphoblastic leukaemia: a systematic genetic study. Lancet Oncol. 2015;16(16):1659-1666.

153. Poggi M, et al. Germline variants in ETV6 underlie reduced platelet formation, platelet dysfunction and increased levels of circulating CD34+ progenitors. Haematologica. 2017;102(2):282-294.

154. Feurstein S, Godley LA. Germline ETV6 mutations and predisposition to hematological malignancies. Int J Hematol. 2017;106(2):189-195.

155. Melazzini F, et al. Clinical and pathogenic features of ETV6-related thrombocytopenia with predisposition to acute lymphoblastic leukemia. Haematologica. 2016;101(11):1333-1342.

156. Landschulz WH, Johnson PF, Adashi EY, Graves $\mathrm{BJ}, \mathrm{McKnight}$ SL. Isolation of a recombinant copy of the gene encoding C/EBP. Genes Dev.
1988;2(7):786-800.

157. Landschulz WH, Johnson PF, McKnight SL. The leucine zipper: a hypothetical structure common to a new class of DNA binding proteins. Science. 1988;240(4860):1759-1764.

158. Vinson CR, Hai T, Boyd SM. Dimerization specificity of the leucine zipper-containing bZIP motif on DNA binding: prediction and rational design. Genes Dev. 1993;7(6):1047-1058.

159. Baxevanis AD, Vinson CR. Interactions of coiled coils in transcription factors: where is the specificity? Curr Opin Genet Dev. 1993;3(2):278-285.

160.Agre P, Johnson PF, McKnight SL. Cognate DNA binding specificity retained after leucine zipper exchange between GCN4 and C/EBP. Science. 1989;246(4932):922-926.

161. Wang ND, et al. Impaired energy homeostasis in C/EBP alpha knockout mice. Science. 1995;269(5227):1108-1112.

162.Zhang DE, Zhang P, Wang ND, Hetherington CJ, Darlington GJ, Tenen DG. Absence of granulocyte colony-stimulating factor signaling and neutrophil development in CCAAT enhancer binding protein alpha-deficient mice. Proc Natl Acad Sci U S A. 1997;94(2):569-574.

163. Guo H, Ma O, Speck NA, Friedman AD. Runx1 deletion or dominant inhibition reduces Cebpa transcription via conserved promoter and distal enhancer sites to favor monopoiesis over granulopoiesis. Blood. 2012;119(19):4408-4418.

164.Wouters BJ, Löwenberg B, Erpelinck-Verschueren CA, van Putten WL, Valk PJ, Delwel R. Double CEBPA mutations, but not single CEBPA mutations, define a subgroup of acute myeloid leukemia with a distinctive gene expression profile that is uniquely associated with a favorable outcome. Blood. 2009;113(13):3088-3091.

165. Pabst T, et al. Dominant-negative mutations of CEBPA, encoding CCAAT/enhancer binding protein-alpha (C/EBPalpha), in acute myeloid leukemia. Nat Genet. 2001;27(3):263-270.

166. Gombart AF, et al. Mutations in the gene encoding the transcription factor CCAAT/enhancer binding protein alpha in myelodysplastic syndromes and acute myeloid leukemias. Blood. 2002;99(4):1332-1340.

167. Kaeferstein A, et al. The emergence of a C/ EBPalpha mutation in the clonal evolution of MDS towards secondary AML. Leukemia. 2003;17(2):343-349.

168. Preudhomme C, et al. Favorable prognostic significance of CEBPA mutations in patients with de novo acute myeloid leukemia: a study from the Acute Leukemia French Association (ALFA). Blood. 2002;100(8):2717-2723.

169.Pulikkan JA, Tenen DG, Behre G. C/EBP $\alpha$ deregulation as a paradigm for leukemogenesis. Leukemia. 2017;31(11):2279-2285.

170.Pabst T, Eyholzer M, Haefliger S, Schardt J, Mueller BU. Somatic CEBPA mutations are a frequent second event in families with germline CEBPA mutations and familial acute myeloid leukemia. JClin Oncol. 2008;26(31):5088-5093.

171. Tawana K, et al. Disease evolution and outcomes in familial AML with germline CEBPA mutations. Blood. 2015;126(10):1214-1223.

172. Smith ML, Cavenagh JD, Lister TA, Fitzgibbon J. Mutation of CEBPA in familial acute myeloid leu- 
kemia. N EnglJMed.2004;351(23):2403-2407.

173. Sellick GS, Spendlove HE, Catovsky D, PritchardJones K, Houlston RS. Further evidence that germline CEBPA mutations cause dominant inheritance of acute myeloid leukaemia. Leukemia. 2005;19(7):1276-1278.

174. Kirstetter P, et al. Modeling of C/EBPalpha mutant acute myeloid leukemia reveals a common expression signature of committed myeloid leukemia-initiating cells. Cancer Cell. 2008;13(4):299-310.

175. Taskesen E, et al. Prognostic impact, concurrent genetic mutations, and gene expression features of AML with CEBPA mutations in a cohort of 1182 cytogenetically normal AML patients: further evidence for CEBPA double mutant AML as a distinctive disease entity. Blood. 2011;117(8):2469-2475.

176. Pathak A, et al. Whole exome sequencing reveals a C-terminal germline variant in CEBPAassociated acute myeloid leukemia: 45 -year follow up of a large family. Haematologica. 2016;101(7):846-852.

177. Bereshchenko O, et al. Hematopoietic stem cell expansion precedes the generation of committed myeloid leukemia-initiating cells in C/EBP $\alpha$ mutant AML. Cancer Cell. 2009;16(5):390-400.

178. Barjesteh van Waalwijk van Doorn-Khosrovani $\mathrm{S}$, et al. Biallelic mutations in the CEBPA gene and low CEBPA expression levels as prognostic markers in intermediate-risk AML. Hematol J. 2003;4(1):31-40.

179. Lin LI, et al. Characterization of CEBPA mutations in acute myeloid leukemia: most patients with CEBPA mutations have biallelic mutations and show a distinct immunopheno- type of the leukemic cells. Clin Cancer Res. 2005;11(4):1372-1379.

180. Tawana K, Rio-Machin A, Preudhomme C, Fitzgibbon J. Familial CEBPA-mutated acute myeloid leukemia. Semin Hematol. 2017;54(2):87-93.

181. Iizuka H, et al. Targeted gene correction of RUNX1 in induced pluripotent stem cells derived from familial platelet disorder with propensity to myeloid malignancy restores normal megakaryopoiesis. Exp Hematol. 2015;43(10):849-857.

182. Connelly JP, et al. Targeted correction of RUNX1 mutation in FPD patient-specific induced pluripotent stem cells rescues megakaryopoietic defects. Blood. 2014;124(12):1926-1930.

183. Katsumura KR, Yang C, Boyer ME, Li L, Bresnick EH. Molecular basis of crosstalk between oncogenic Ras and the master regulator of hematopoiesis GATA-2. EMBO Rep. 2014;15(9):938-947.

184. Katsumura KR, Ong IM, DeVilbiss AW, Sanalkumar R, Bresnick EH. GATA factor-dependent positive-feedback circuit in acute myeloid leukemia cells. Cell Rep. 2016;16(9):2428-2441.

185. Wang Q, et al. ETV6 mutation in a cohort of 970 patients with hematologic malignancies. Haematologica. 2014;99(10):e176-e178.

186.Bejar R, et al. Clinical effect of point mutations in myelodysplastic syndromes. $N$ Engl JMed. 2011;364(26):2496-2506.

187. Bhojwani D, et al. ETV6-RUNX1-positive childhood acute lymphoblastic leukemia: improved outcome with contemporary therapy. Leukemia. 2012;26(2):265-270.

188. Van Vlierberghe P, et al. ETV6 mutations in early immature human T cell leukemias. JExp Med. 2011;208(13):2571-2579.

189. Kuehn HS, et al. Loss of B cells in patients with heterozygous mutations in IKAROS. $N$ Engl J Med. 2016;374(11):1032-1043.

190.Churchman ML, et al. Germline genetic IKZF1 variation and predisposition to childhood acute lymphoblastic leukemia. Cancer Cell. 2018;33(5):937-948.e8.

191. Boutboul D, et al. Dominant-negative IKZF1 mutations cause a T, B, and myeloid cell combined immunodeficiency. JClin Invest. 2018;128(7):3071-3087.

192.Mullighan CG, et al. Deletion of IKZF1 and prognosis in acute lymphoblastic leukemia. $N$ EnglJ Med. 2009;360(5):470-480.

193. Marke R, van Leeuwen FN, Scheijen B. The many faces of IKZF1 in B-cell precursor acute lymphoblastic leukemia. Haematologica. 2018;103(4):565-574.

194. Shah S, et al. A recurrent germline PAX5 mutation confers susceptibility to pre-B cell acute lymphoblastic leukemia. Nat Genet. 2013;45(10):1226-1231.

195. Mullighan CG, et al. Genome-wide analysis of genetic alterations in acute lymphoblastic leukaemia. Nature. 2007;446(7137):758-764.

196. Nebral K, et al. Incidence and diversity of PAX5 fusion genes in childhood acute lymphoblastic leukemia. Leukemia. 2009;23(1):134-143.

197. Urbánek P, Wang ZQ, Fetka I, Wagner EF, Busslinger M. Complete block of early B cell differentiation and altered patterning of the posterior midbrain in mice lacking Pax5/BSAP. Cell. 1994;79(5):901-912. 